\title{
Optimization of the Recovery of Secondary Metabolites from Defatted Brassica carinata Meal and Its Effects on the Extractability and Functional Properties of Proteins
}

\author{
V. P. Thinh Nguyen ${ }^{1,2}$, Jon D. Stewart ${ }^{2}$, Florent Allais ${ }^{1}$ (D) and Irina Ioannou ${ }^{1, *(D)}$ \\ 1 URD Agro-Biotechnologies Industrielles (ABI), CEBB (Centre Européen de Biotechnologie et de Bioéconomie), \\ AgroParisTech, 51110 Pomacle, France; vpthinh.nguyen@icloud.com (V.P.T.N.); \\ florent.allais@agroparistech.fr (F.A.) \\ 2 Department of Chemistry, University of Florida, Gainesville, FL 32611, USA; jds2@chem.ufl.edu \\ * Correspondence: irina.ioannou@agroparistech.fr
}

check for updates

Citation: Nguyen, V.P.T.; Stewart,

J.D.; Allais, F.; Ioannou, I.

Optimization of the Recovery of

Secondary Metabolites from Defatted

Brassica carinata Meal and Its Effects

on the Extractability and Functional

Properties of Proteins. Foods 2022, 11,

429. https://doi.org/10.3390/

foods 11030429

Academic Editor: Antonio Cilla

Received: 13 January 2022

Accepted: 28 January 2022

Published: 1 February 2022

Publisher's Note: MDPI stays neutral with regard to jurisdictional claims in published maps and institutional affiliations.

Copyright: (c) 2022 by the authors Licensee MDPI, Basel, Switzerland. This article is an open access article distributed under the terms and conditions of the Creative Commons Attribution (CC BY) license (https:// creativecommons.org/licenses/by/ $4.0 /)$.

\begin{abstract}
The sustainable extraction of secondary metabolites from Brassica agro-industrial byproducts often involves the use of high concentrations of ethanol, and/or high temperatures, which tends to decrease the efficiency of protein extraction (yield, profile, etc.). To understand the limits of the combination of these two extraction processes, aqueous ethanol extraction of secondary metabolites (e.g., phenolic compounds and glucosinolates) from Brassica carinata defatted meal was optimized using Response Surface Methodology. The validated models predicted that aqueous ethanol extraction of defatted Carinata meal, with a low aqueous EtOH concentration $(22 \% \mathrm{EtOH})$ at moderate $T_{e}\left(50{ }^{\circ} \mathrm{C}\right)$, enables the efficient recovery of secondary metabolites (sinapine $=9.12 \pm 0.05 \mathrm{mg} / \mathrm{g}_{\mathrm{DM}}$, sinigrin $\left.=86.54 \pm 3.18 \mu \mathrm{mol} / \mathrm{g}_{\mathrm{DM}}\right)$ while maintaining good protein extractability $(59.8 \pm 2.1 \%)$ from successive alkaline extractions. The evaluation of functional properties of the resulting protein isolates revealed that aqueous extraction, under optimized conditions, improves foaming activity while preserving emulsion ability.
\end{abstract}

Keywords: phenolic compounds; glucosinolates; Response Surface Methodology; proteins; Brassica carinata

\section{Introduction}

Historically cultivated in the Ethiopian highlands and adjoining areas of East African and Mediterranean regions for food purposes, Brassica carinata (referred as Carinata) is now considered a nonfood oilseed crop in the United States due to its high erucic acid-rich oil content, which is suitable for aviation biofuel production [1]. Cultivating Carinata in the southeast regions of the USA is believed to be economically and ecologically beneficial for local farmers, by improving soil nutrient and moisture conservation during winter seasons (Southeastern Partnership Advanced Renewable from Carinata [2]. Although the main purpose of such cultivations is to support bio-fuel production, the residual meal still contains valuable components, such as proteins and secondary metabolites [3,4].

The defatted Carinata meal obtained after oil extraction could be an important source of proteins. Indeed, the nutritional value of Carinata is similar to that of rapeseed (B. napus), which is considered to be well-balanced for human nutrition [5-7]. Moreover, the nutritional value of Carinata is comparable to that of other plant-based proteins (soybean, sunflower), and even certain animal-based proteins (casein) [3]. It should be noted that these proteins also have valuable functional properties [8,9] for many applications (e.g., encapsulation of bioactive compounds, drug delivery) $[10,11]$. The secondary metabolites of Carinata meal are mainly phytic acid, phenolic compounds (PCs), and glucosinolates (GSLs) [7,12,13]. Although the therapeutic benefits of these co-product molecules have often been mentioned (e.g., antioxidant, antibacterial, anticancer) [7,14-16], they also exhibit anti-nutritional 
activities at high concentrations, and thereby decrease the nutritional value of meal or protein extracts $[7,17]$. An additional separation step is, therefore, required to remove secondary metabolites from protein extracts. Such a separation process must have a high separation efficiency, without altering the extractability or functional properties of the proteins.

Sustainable and environmentally friendly recovery of bioactive molecules from biomass is attracting ever-increasing attention [18]. The recovery of these metabolites from agroindustrial wastes using aqueous alcohol extraction has become popular [12,19-22]. Although aqueous methanol has traditionally been used to recover phenolic compounds from biomass $[23,24]$, aqueous ethanol (AE) has become more attractive, thanks to its low toxicity [20,22]. Nevertheless, such an extraction process often involves the use of alcohol at high concentrations and/or the use of high temperatures, which can partially alter the solubility and functional properties of proteins, due to structural changes $[25,26]$. To the best of our knowledge, very few studies have focused on the extractability and functional properties of the proteins contained in meal after AE extraction. Indeed, only one study on rapeseed meal has been reported [27], in which the effect of AE extraction under defined conditions $(70 \% \mathrm{EtOH} /$ ultrapure water, room temperature) resulted in an $11 \%$ decrease in protein extractability.

In this article, we carry out a 2-step fractionation of Carinata meal: an AE extraction to recover the secondary metabolites, followed by an alkaline extraction to obtain protein extracts. The objective is to study the effects of AE extraction of secondary metabolites on protein extractability by observing the protein content and polypeptide profile of the extracts. For this, the AE extraction process was optimized using RSM, to maximize either the content of PCs, the content of GSLs, or the content of proteins. Secondly, different optimal operating conditions were compared, and a compromise was found which allowed the extraction of large amounts of PCs and GSLs while maintaining good protein extractability. The effect of these conditions was also evaluated on the functional properties of the residual proteins.

\section{Materials and Methods}

\subsection{Chemicals}

Sinigrin hydrate and sinapic acid, used as external standards, were purchased from Sigma-Aldrich. Pure synthetic sinapine chloride was synthesized in our laboratory and used as the standard for HPLC analysis [22,28]. The ethanol solution used for extraction was purchased from ThermoFisher. LC-MS grade formic acid and acetonitrile, for HPLC analysis, were purchased from ThermoFisher. MilliQ water was produced by Milli-Q Direct 8 (Merck Millipore, MA, USA).

\subsection{Carinata Meal Samples and Their Characterization}

Hexane-solvent extracted Carinata meal was provided by Dr. DiLorenzo (IFAS, University of Florida, FL, USA). The meal was ground, passed through a 30-mesh screen (500 microns), and stored at $-20{ }^{\circ} \mathrm{C}$ until use. The water content of the meal was determined to be $88.8 \pm 0.4 \mathrm{mg} / \mathrm{g}$ of Carinata meal using a standard moisture analyzer; MB35-OHAUS ${ }^{\text {TM }}$ (OHAUS, New Jersey, NJ, USA). Ash and protein contents were determined using AOAC approved methods [29]. Soluble carbohydrate and phytic acid contents were determined using the protocol described by Dubois et al. and Reichwald and Hatzack, respectively $[30,31]$.

\subsection{Fractionation Process of Carinata Meal}

The fractionation process involves two successive extractions, as shown in Figure 1.

Five grams of defatted B. carinata meal were extracted with $50 \mathrm{~mL}$ of a mixture of $\mathrm{EtOH} / \mathrm{MilliQ}$ water for $1 \mathrm{~h}$ at $300 \mathrm{rpm}$. The EtOH concentration and extraction temperature varied according to the design of the experiment, as presented below. The slurry was centrifuged for $20 \mathrm{~min}$ at $4000 \mathrm{rpm}$ and $25{ }^{\circ} \mathrm{C}$ using a refrigerated benchtop centrifuge 
Allegra X15-R (Beckman Coulter, Pasadena, CA, USA). After centrifugation, the supernatant (henceforth referred as the AE extract) and residual meal (pellet) were recovered. The AE extract was evaporated under vacuum to remove EtOH. The concentrated liquid was freeze-dried, weighed, and stored at room temperature. The contents of sinapine and sinigrin in the AE extracts were determined, along with the nitrogen solubility and the polypeptide profile. The residual meal was air-dried overnight (referred as treated Carinata meal), and then stored at $4{ }^{\circ} \mathrm{C}$ for a maximum of 2 days prior to alkaline extraction.

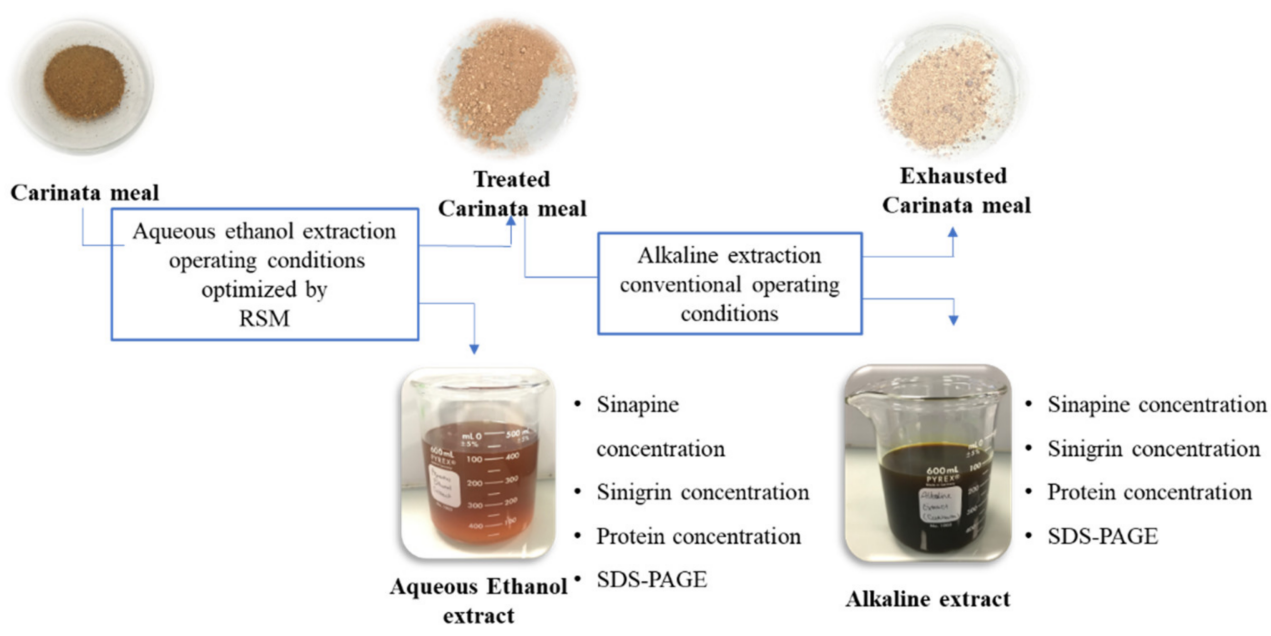

Figure 1. Fractionation of Carinata meal.

Alkaline extraction was performed following the published procedure, with slight modifications [3]. In brief, treated Carinata meal was extracted with $50 \mathrm{~mL}$ of $0.1 \mathrm{M} \mathrm{KOH}$ at $300 \mathrm{rpm}$ for $30 \mathrm{~min}$. A pH value 12 was recorded using a $\mathrm{pH}$ meter SevenCompact $\mathrm{pH} / \mathrm{Ion}$ meter S220 (Mettler Toledo, OH, USA). The slurry was centrifuged for $20 \mathrm{~min}$ at $4000 \mathrm{rpm}$ and $25^{\circ} \mathrm{C}$. After centrifugation, the supernatant (protein extract) and pellet (exhausted meal) were recovered. The protein extract was freeze-dried, weighed, and stored at room temperature. The same analysis used previously for the AE extracts was also carried out for the protein extracts. The control was represented by protein extract obtained from the original Carinata meal by alkaline extraction (with no prior AE step).

\subsection{Determination of Phenolic Compound and Glucosinolate Contents}

HPLC quantification of PCs was performed as described elsewhere [22] on a UHPLCDAD system (Ultimate 3000, Dionex, ThermoFisher, MA, USA) equipped with a quadratic pump, auto sampler, column furnace, and diode array detector. Data were analyzed with Chromeleon software (Version 6.8, Thermofisher, MA, USA). Main PCs, including sinapine and sinapic acid, were identified by comparing their relative retention time to a standard. Synthetic sinapine chloride was used in the preparation of the calibration curve.

The GSL content was determined following procedure described by Grosser and van Dam, with some modifications [32]. Samples were diluted ten times prior to the desulfation step. One milliliter of sample was loaded onto a glass pipette, preconditioned with $0.5 \mathrm{~mL}$ of Sephadex A25 $0.1 \mathrm{mg} / \mathrm{mL}$ in MilliQ-water. A total of $2 \times 1 \mathrm{~mL}$ of MilliQ-water was used for washing. The column was next washed with $2 \times 1 \mathrm{~mL}$ of acetate buffer $(40 \mathrm{mM}, \mathrm{pH}$ 5.5). Twenty microliters of cleaned-up Helix pomatia sulfatase solution (S9626, Sigma-Aldrich) was added onto the column, followed by flushing with $50 \mu \mathrm{L}$ of acetate buffer. The column was incubated at room temperature prior to eluting with $2 \times 1 \mathrm{~mL}$ of MilliQ-water. The eluted fraction was then analyzed by UHPLC.

\subsection{Determination of Protein Content of AE Extracts}

The protein content of AE extracts was calculated based on the nitrogen solubility, according to the AOAC approved method [29], and is shown in Equation (1): 


$$
\mathrm{C}_{\text {protein }}=\frac{\% \mathrm{~N} \times 6.25 \times \mathrm{m}_{\text {lyoph extract }}}{\mathrm{m}_{\mathrm{DM}}},
$$

where $\% \mathrm{~N}$ is the nitrogen content of freeze-fried extracts, determined by combustion following the Dumas method. $\mathrm{M}_{\text {lyoph extract }}$ is the mass of freeze-dried supernatant $(\mathrm{g})$, and $\mathrm{m}_{\mathrm{DM}}$ is the mass of dry matter in Carinata meal $(\mathrm{g})$.

The nitrogen content $(\% \mathrm{~N})$ of freeze-dried $\mathrm{AE}$ and protein extracts was determined using the Dumas method, performed by UMR 614 Institut National de la Recherche AgronomiqueUniversité de Reims Champagne-Ardennes (INRA-URCA) commercial services.

\subsection{Analysis of Polypeptide Profile}

The polypeptide profiles of AE and alkaline extracts were analyzed using electrophoresis. Sodium dodecyl sulfate polyacrylamide gel electrophoresis (SDS-PAGE) was carried out following standard procedure under non-reducing conditions. In brief, around $10 \mathrm{mg}$ of freeze-dried supernatant was dissolved in $1 \mathrm{~mL}$ of MilliQ-water, with vortex mixing to resuspend the solid. Fifteen microliters of this solution were mixed with $5 \mu \mathrm{L}$ of $4 \mathrm{X}$ Laemmli Sample Buffer (Biorad, Hercules, CA, USA). The mixture was boiled for 15 min and cooled at room temperature for $30 \mathrm{~min}$. Twenty microliter aliquots were then loaded onto the precast gradient gels MiniProtein TGX 4-15\% Strain Free (Biorad, Hercules, CA, USA), along with $15 \mu \mathrm{L}$ of standard proteins SpectraTM Multicolor Broadrange (Thermo Fisher, Waltham, MA, USA). Separation of samples was performed for $1 \mathrm{~h}$ at $20 \mathrm{~mA}$ per gel.

\subsection{Optimization of the AE Extraction of Secondary Metabolites}

A D-optimal design was used to optimize the operating conditions of the AE extraction of secondary metabolites, with a total of 13 experiments and a triplicate at the central point (Table 1). The independent variables used in this optimization were the concentration of ethanol $\left(\% \mathrm{EtOH}, \mathrm{X}_{1}\right)$ and the extraction temperature $\left(\mathrm{T}_{\mathrm{e}}, \mathrm{X}_{2}\right)$. The significant contributions of $\% E t O H$ and $\mathrm{T}_{\mathrm{e}}$ to the recovery yield of secondary metabolites were recently reported $[20,22]$. As a result, $\% \mathrm{EtOH}$ and $\mathrm{T}_{\mathrm{e}}$ were varied to four different levels $(25,45$, 70 and $90 \%$ ) and three different levels $\left(25,50\right.$ and $\left.75{ }^{\circ} \mathrm{C}\right)$, respectively. The limit was set at $75{ }^{\circ} \mathrm{C}$ to avoid loss of solvent by evaporation. Other solid-liquid extraction parameters, including extraction time, solvent-solid ratio, and extracting materials' particle size, remained constant, as these were thought to be non-significant in the context of our study.

Table 1. D-optimal experimental design.

\begin{tabular}{ccc}
\hline Experiments & \%EtOH $(\mathbf{\%}) \mathbf{X}_{\mathbf{1}}$ & $\mathbf{T}_{\mathbf{e}}\left({ }^{\circ} \mathbf{C}\right) \mathbf{X}_{\mathbf{2}}$ \\
\hline 0 & 0 & 25 \\
1 & 70 & 50 \\
2 & 20 & 25 \\
3 & 70 & 50 \\
4 & 20 & 50 \\
5 & 45 & 50 \\
6 & 20 & 75 \\
7 & 70 & 25 \\
8 & 70 & 50 \\
9 & 90 & 25 \\
10 & 20 & 25 \\
11 & 90 & 50 \\
12 & 45 & 75 \\
13 & 70 & 75 \\
\hline
\end{tabular}

Three responses were optimized: the phenolic compound content $\left(\mathrm{Y}_{1}\right)$, the sinigrin content $\left(\mathrm{Y}_{2}\right)$, and the extractability index of proteins $\left(\mathrm{Y}_{3}\right)$ of the AE extracts.

Under some conditions, sinapine can be hydrolyzed in sinapic acid, these two molecules being the two main phenolic compounds in Carinata meal. Thus, the PCs determined 
herein include both the sinapine and sinapic acid contributions. $Y_{1}$ is expressed according to the dry matter and calculated as shown in Equation (2):

$$
\mathrm{Y}_{1}=\frac{\left(\mathrm{C}_{\text {sinapine }}+\mathrm{C}_{\text {sinapic acid }}\right) \times \mathrm{m}_{\text {extract }}}{\mathrm{d} \times \mathrm{m}_{\mathrm{DM}}},
$$

where $\mathrm{C}_{\text {sinapine }}$ is the concentration of sinapine in $\mathrm{AE}$ extract (in $\mathrm{mg} / \mathrm{mL}$ ), $\mathrm{C}_{\text {sinapic acid }}$ the concentration of sinapic acid in AE extract $(\mathrm{mg} / \mathrm{mL}), \mathrm{m}_{\text {extract }}$ the mass of extract $(\mathrm{g}), \mathrm{d}$ the volumetric mass density $(\mathrm{g} / \mathrm{mL})$, and $\mathrm{m}_{\mathrm{DM}}$ the mass of dry matter in Carinata meal $(\mathrm{g})$.

The GSL content of AE extracts $\left(\mathrm{Y}_{2}\right)$ is expressed according to the dry matter and calculated as shown in Equation (3):

$$
\mathrm{Y}_{2}=\frac{\mathrm{C}_{\mathrm{GSL}} \times\left(\mathrm{m}_{\mathrm{extract}}\right)}{\mathrm{d} \times \mathrm{m}_{\mathrm{DM}}},
$$

where $\mathrm{C}_{\mathrm{GSL}}$ is the concentration of GSL (as sinigrin) in AE extract $(\mu \mathrm{mol} / \mathrm{mL}), \mathrm{m}_{\text {extract }}$ is the mass of the extract $(\mathrm{g}), \mathrm{d}$ is the volumetric mass density $(\mathrm{g} / \mathrm{mL})$, and $\mathrm{m}_{\mathrm{DM}}$ the mass of dry matter in Carinata meal (g).

AE extraction mainly impacts their extractability $\left(\mathrm{Y}_{3}\right)$ of proteins in this optimization study. The protein content of the different extracts was calculated according to Equation (1). By taking the protein content of the control (alkaline extracts from untreated Carinata meal) as the maximum content that can be extracted, we can define an extractability index, as described in Equation (4):

$$
Y_{3}=\frac{\mathrm{C}_{\text {protein }} \times \mathrm{m}_{\text {extract }}}{\mathrm{C}_{\text {protein control }} \times \mathrm{m}_{\text {control }}} \times 100 \%,
$$

where $C_{\text {protein }}$ is the protein content of alkaline extract from residual meal upon AE extraction $\left(\mathrm{mg} / \mathrm{g}_{\mathrm{DM}}\right), \mathrm{m}_{\text {extract }}$ is the mass of the extract $(\mathrm{g})$, and $\mathrm{C}_{\text {protein control }}$ is the protein content of the alkaline extract from the control Carinata meal $\left(\mathrm{mg} / \mathrm{g}_{\mathrm{DM}}\right)$.

The experimental data were fitted using a second-order polynomial equation:

$$
Y_{q}=\beta_{0}+\sum_{i=1}^{2} \beta_{i} X_{i}+\sum_{i=1}^{2} \beta_{i i} X_{i}^{2}+\sum \sum_{i<j=1}^{2} \beta_{i j} X_{i} X_{j}+\varepsilon_{\text {residues } q}
$$

Yq is the different responses $(q=1-3) ; \beta 0, \beta i, \beta i j$, and $\beta i i$ are the regression coefficients of the mean, linear, interaction, and quadratic terms, respectively; $X_{i}$ and $X_{j}$ are the independent variables; and $\varepsilon_{\text {residues } q}$ is the difference between the observed and the predicted value.

Experimental design and analysis were performed using the software MODDE v.12.0 (Satorius, Gottingen, Germany). An analysis of variance (ANOVA) with $95 \%$ confidence level was carried out for each response to test the model significance and adequacy. The model coefficients were considered as significant when the Student's $t$-tests of significatively give a $p$-value inferior to 0.05 . Surface responses were plotted for each response in order to observe the effects of the different terms of the model.

\subsection{Determination of Optimal Operating Conditions}

MODDE-a Nelder-Mead simplex method-based software optimizer tool—was used to find the optimal operating condition for the recovery of secondary metabolites.

To determine those maximizing the recovery of secondary metabolites and protein extractability, Microsoft Excel (Version 16.43) was used. Indeed, the $Y_{1}, Y_{2}$, and $Y_{3}$ responses vary antagonistically, and the MODDE optimizer tool was defeated. We plotted graphs in which $Y_{1}, Y_{2}$, and $Y_{3}$ values were calculated using prediction models according to the $\% \mathrm{EtOH}$ for a fixed extraction temperature. Thus, six graphs were plotted for extraction temperatures ranging from 25 to $50{ }^{\circ} \mathrm{C}$ in five-degree steps. $\mathrm{T}_{\mathrm{e}}$ was limited to $50{ }^{\circ} \mathrm{C}$ to avoid the dissociation of certain proteins, such as cruciferin [33]. The optimum zone, 
corresponding to the meeting point of the three models for which the three responses were the highest, was determined for each graph.

\subsection{Functional Properties}

\subsubsection{Preparation of Acid-Precipitated Isoelectric Protein Isolates}

Aluko and McIntosh's procedure was used to produce acid-precipitated isoelectric protein isolate for functional property analyses [34]. In brief, Carinata meal was extracted with 10 volumes of $0.1 \mathrm{M} \mathrm{NaOH}$ for $30 \mathrm{~min}$ at $300 \mathrm{rpm}$ and room temperature. The slurry was then centrifuged for $20 \mathrm{~min}$ at $4000 \mathrm{rpm}$ and $25^{\circ} \mathrm{C}$. The supernatant was then separated from the residue and gradually adjusted to $\mathrm{pH} 4$ using $1 \mathrm{M} \mathrm{HCl}$. The precipitate was then recovered by centrifugation, washed twice with 10 volumes of MilliQ-water, freeze-dried, weighed, and stored at $-20^{\circ} \mathrm{C}$ until further analyses.

\subsubsection{Emulsifying Activity Index}

The emulsifying activity index (EAI) was determined following the procedure described by Aluko and McIntosh [34]. Protein solutions (1\% w/v) were prepared in $0.01 \mathrm{M}$ phosphate buffer ( $\mathrm{pH} 7.0$ ), and $5 \mathrm{~mL}$ of the latter was added to $1 \mathrm{~mL}$ of pure commercial canola oil. The protein solution and oil phase were homogenized at 16,000 rpm for $1 \mathrm{~min}$ using a T25 digital Ultra-Turrax (IKA-Works, Inc., Cincinnati, OH, USA). Ten microliters of the emulsion was immediately diluted to $5 \mathrm{~mL}$ with $0.1 \%(w / v)$ SDS solution $(0.1 \mathrm{~g} / 100 \mathrm{~mL})$, and the absorbance at $500 \mathrm{~nm}$ was measured using the $0.1 \%$ SDS solution as a blank. The EAI ( $\mathrm{m}^{2} / \mathrm{g}$ ) was calculated as described in Equation (6), according to the Pearce and Kinsella method [35]. The emulsions were allowed to stand at room temperature for $30 \mathrm{~min}$, and the EAI was determined and expressed as a percentage of the initial EAI to obtain emulsion stability (ES).

$$
\mathrm{EAI}=\frac{2 \times 2.303 \times \mathrm{A} \times \mathrm{N}}{\mathrm{C} \times \varphi \times 10000}
$$

where $\mathrm{A}$ is the absorbance recorded at $500 \mathrm{~nm}, \mathrm{~N}$ is the dilution factor $(\times 500), \mathrm{C}$ the protein concentration before the formation of the emulsion $(\mathrm{g} / \mathrm{mL})$, and $\varphi$, the volume fraction of the oil (mL).

\subsubsection{Foam Expansion (FE) and Foam Stability (FS)}

FE was determined according to the protocol described by Aluko and McIntosh [34]. Ten milliliters of protein solution $(1 \% \mathrm{w} / \mathrm{v})$, prepared in $0.01 \mathrm{M}$ sodium phosphate buffer (pH 7.0) was homogenized at $16,000 \mathrm{rpm}$ for $30 \mathrm{~s}$. The volume of foam obtained was expressed as a percentage of the initial volume of protein solution. FS was determined by measuring the volume of foam that remained after standing at room temperature for $30 \mathrm{~min}$, expressed as a percentage of the initial foam volume.

\subsection{Statistical Analysis}

Each analysis was performed in duplicate. Results correspond to the mean associated to its standard deviation. Student's $t$-test, ANOVA, and post-hoc analysis using Tukey's test were carried out using RStudio (Version 3.6.1, RStudio Inc., Boston, MA, USA).

\section{Results}

Ash and protein contents were determined to be $72.0 \pm 0.2 \mathrm{mg} / \mathrm{g}$ of dry matter (mg/g $/$ Dry Matter (DM) $)$ and $499.1 \pm 1.7 \mathrm{mg} / \mathrm{g}_{\mathrm{DM}}$, respectively. Soluble carbohydrates corresponded to $74.7 \pm 3.7 \mathrm{mg} / \mathrm{g}_{\mathrm{DM}}$, and the content of phytic acid was $7.6 \pm 0.4 \mathrm{mg} / \mathrm{g}_{\mathrm{DM}} \mathrm{using}$ the colorimetric method. The remaining residue was composed of fibers and secondary metabolites, including PCs and GSLs. These chemical compositions are similar to those of defatted Carinata meal reported by other studies $[3,36]$.

In a successful double valorization of Carinata meal, the extraction of secondary metabolites, carried out in the first step, must have a slight impact on the extractability and functional properties of the proteins obtained in the second extraction. In this context, 
the extraction process of PCs and GSLs was optimized, and the impact of the optimal operating conditions on proteins was studied. The AE extraction was performed prior to the alkaline extraction to avoid the amalgam extraction of proteins along with secondary metabolites, which would require a more complicated downstream separation are reported in Figures S1 and S2 (Supplementary Materials).

\subsection{Optimization of Aqueous Ethanol Extraction using Response Surface Methodology}

A D-optimal design was used to optimize the operating conditions for AE extraction of Carinata defatted meal based on the secondary metabolite contents. Two independent variables_ $\%$ EtOH with four levels $(25,45,70$, and $90 \%)$ and $\mathrm{T}_{\mathrm{e}}$ with three levels $(25,50$, and $75{ }^{\circ} \mathrm{C}$ )—-were selected as factors. The responses upon optimization were $\mathrm{Y}_{1}$ the PC content, $\mathrm{Y}_{2}$ the GSL content, and $\mathrm{Y}_{3}$ the extractability index of proteins.

\subsubsection{Model Adequacy}

The D-optimal design generated by optimizer software resulted in 13 extractions. Multiple regression equations using polynomial second order were applied to afford the responses. Analysis of variance (ANOVA) was then conducted to determine the regression coefficients of each model. Table 2 summarizes the statistical parameters obtained in this study.

Table 2. Model equation coefficients and statistical parameters.

\begin{tabular}{cccc}
\hline \multirow{2}{*}{ Factors } & \multicolumn{3}{c}{ Coefficient Values } \\
\cline { 2 - 4 } & $\mathbf{Y}_{\mathbf{1}}$ & $\mathbf{Y}_{\mathbf{2}}$ & $\mathbf{Y}_{\mathbf{3}}$ \\
\cline { 2 - 4 } Constant & 1.0333 & 1.9744 & -1.7016 \\
$\% \mathrm{EtOH}$ & $0.0028^{\mathrm{NS}}$ & -0.0864 & $-0.0080^{\mathrm{NS}}$ \\
$\mathrm{T}_{\mathrm{e}}$ & $0.0144^{\mathrm{NS}}$ & $0.0221^{\mathrm{NS}}$ & -0.0529 \\
$\% \mathrm{EtOH} \times \% \mathrm{EtOH}$ & -0.0457 & -0.0847 & 0.0818 \\
$\mathrm{~T}_{\mathrm{e}} \times \mathrm{T}_{\mathrm{e}}$ & $-0.0145^{\mathrm{NS}}$ & $-0.0126^{\mathrm{NS}}$ & $-0.0108^{\mathrm{NS}}$ \\
$\% \mathrm{H} \mathrm{H} \times \mathrm{T}_{\mathrm{e}}$ & -0.0220 & $0.0143^{\mathrm{NS}}$ & -0.0717 \\
$\mathrm{R}^{2}$ & 0.869 & 0.929 & 0.849 \\
$\mathrm{R}^{2}$ adjusted & 0.775 & 0.870 & 0.763 \\
Regression $(p$-value & $5.4 \times 10^{-3}$ & $2.2 \times 10^{-3}$ & $5.3 \times 10^{-3}$ \\
Lack of fit & 0.324 & 0.708 & 0.273 \\
Reproducibility & 0.847 & 0.820 & 0.900 \\
Condition number & 4.654 & 4.683 & 3.605 \\
\hline
\end{tabular}

NS denotes non-significant; coefficients in green are significant.

Coefficients were considered significant for $p<0.05$. Non-significant coefficients were removed to obtain reduced models when the predictive capacity of the model was not decreased. The coefficients of determination of the three prediction models indicated good model accuracy $\left(\mathrm{R}^{2}>0.8\right)$. The adjusted determination coefficients furthermore confirmed the adequacy of the established models $\left(\mathrm{R}^{2}\right.$ adjusted $\left.>0.75\right)$. The orthogonality of all models was determined to be satisfactory, as the condition numbers were inferior to 10 . With good reproducibility values $(>0.8)$, the relationships between the variables and the responses were well depicted by these models.

\subsubsection{Phenolic Compound and Sinigrin Contents in Aqueous Ethanol Extracts $\left(Y_{1}\right.$ and $\left.Y_{2}\right)$}

Variations of $Y_{1}$ and $Y_{2}$ were found among the experiments of the D-optimal design. $Y_{1}$ ranged from 7.26 to $11.33 \mathrm{mg} / \mathrm{gDM}$ (Table S1), whereas $Y_{2}$ ranged from 32.58 to $94.01 \mu \mathrm{mol} / \mathrm{g}_{\mathrm{DM}}$ (Table S2). Model equations are given in Supplementary Materials. Response surfaces were plotted to see the effect of the different variables on the responses (Figure 2).

According to Table 2, the most significant terms in the model equation providing $\mathrm{Y}_{1}$ are the quadratic term for the ethanol content $(\% \mathrm{EtOH} \times \% \mathrm{EtOH})$ and the interaction between the ethanol concentration and temperature $\left(\% \mathrm{EtOH} \times \mathrm{T}_{\mathrm{e}}\right)$, which have a negative 
impact on the recovery of phenolic compounds (Figure 2a). These results are consistent with other studies $[37,38]$. Reungoat et al. showed that $\% \mathrm{EtOH} \times \% \mathrm{EtOH}$ leads to a negative effect on $\mathrm{AE}$ extraction of sinapine from mustard bran $(-3 \mathrm{mg} / \mathrm{gDM})$ [22]. In contrast to other studies, the quadratic term for $\mathrm{T}_{\mathrm{e}}$ in this study was unsignificant. The use of different types of biomasses (defatted meal instead of bran) for the AE extraction was suggested to account for the differences observed [22,38]. The prediction model showed that the highest content of phenolic compounds (over $10.2 \mathrm{mg} / \mathrm{gDM}$ ) was reached for a $\% \mathrm{EtOH}$ varying from 40 to $70 \%$. In contrast, the recovery was significantly decreased for an extraction carried out with a \%EtOH less than $40 \%$ or greater $70 \%$, as depicted in Figure 2.

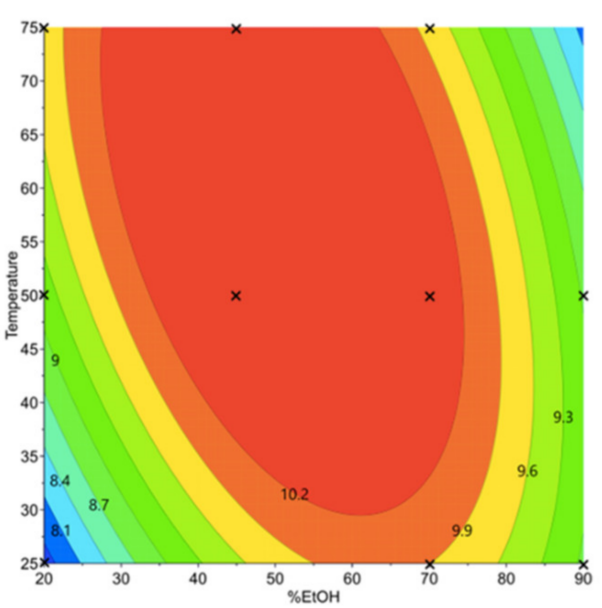

(a)

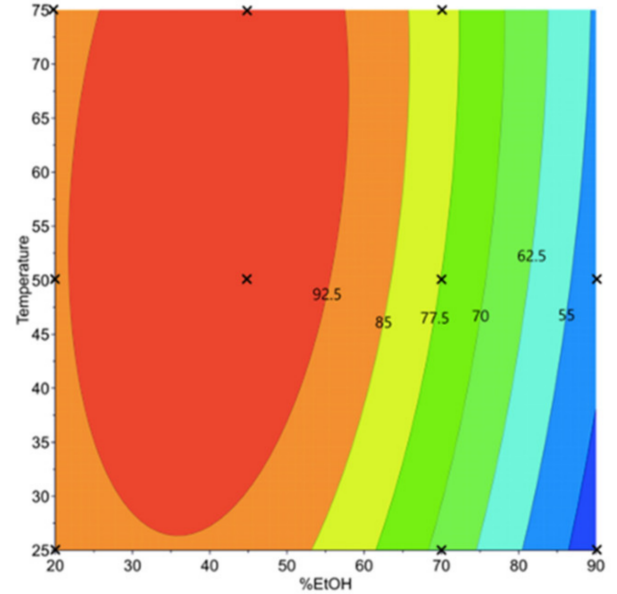

(b)

Figure 2. Contour plots for the prediction of phenolic compound ( $\left.\mathrm{mg} / \mathrm{g}_{\mathrm{DM}}\right)(\mathbf{a})$ and glucosinolate contents $\left(\mu \mathrm{mol} / \mathrm{g}_{\mathrm{DM}}\right)(\mathbf{b})$. The crosses indicate data points that were fitted for plot building.

According to Figure $2 b$, a negative effect of the quadratic term of ethanol concentration $(\% \mathrm{EtOH} \times \% \mathrm{EtOH})$ on sinigrin recovery is observed, whereas the other terms related to $\mathrm{T}_{\mathrm{e}}$ do not significantly contribute to the recovery of this metabolite. These results were expected, as a conventional sinigrin recovery process was used. Indeed, the latter being very hydrophilic due to the ionized sulfate and hydrophilic thioglucose moieties, a solidliquid extraction with an alcohol/water mixture is appropriate [32,39]. However, since GSLs are highly hydrophilic, their content in AE extracts appears to be more sensitive to the variation of \%EtOH than PCs. More than half of the amount of GSLs is reduced by increasing the $\% \mathrm{EtOH}$ from $40 \%$ to $90 \%$.

\subsubsection{Determination of the Optimal Conditions of Aqueous Ethanol Extraction and} Validation of the Prediction Models

The results suggested that, through the AE extraction, PCs and GSLs can be simultaneously and optimally recovered from defatted Carinata meal. The optimal conditions, suggested by the MODDE software based on the previously established models, are $\% \mathrm{EtOH}=47 \%$ and $\mathrm{T}_{\mathrm{e}}=62{ }^{\circ} \mathrm{C}$. Under these conditions, the contents of PCs and GSLs, predicted by the models, were determined to be $11.74 \pm 1.26 \mathrm{mg} / \mathrm{g}_{\mathrm{DM}}$ and $103.6 \pm 16.2 \mu \mathrm{mol} / \mathrm{g}_{\mathrm{DM}}$, respectively. These values remain statistically similar (Table S3) to the values observed $\left(10.87 \pm 0.54 \mathrm{mg} / \mathrm{g}_{\mathrm{DM}}\right.$ and $98.9 \pm 4.9 \mu \mathrm{mol} / \mathrm{g}_{\mathrm{DM}}$ for the PCs and GSLs, respectively), and thus confirmed the validity of the prediction models for $Y_{1}$ and $Y_{2}$.

\subsection{Effects of Aqueous Ethanol Extraction on Carinata Proteins}

The previous D-optimal design was also used to optimize $Y_{3}$, the extractability index of the proteins in AE extracts. 


\subsubsection{Extractability of Proteins Resided in Carinata Treated Meal $\left(\mathrm{Y}_{3}\right)$}

Considering the characteristics of the proteins, their extractability can be influenced by the processes used prior their extraction [39]. Thus, the effect of the AE extraction process of secondary metabolites on the extractability of proteins $\left(\mathrm{Y}_{3}\right)$ was studied and quantified using RSM. Variations of $Y_{3}$ were found among the experiments of D-optimal design, and ranged from 41.3 to $54.5 \%$ (Table S4).

Optimal zones to obtain a high extractability index of proteins are shown in Figure 3.

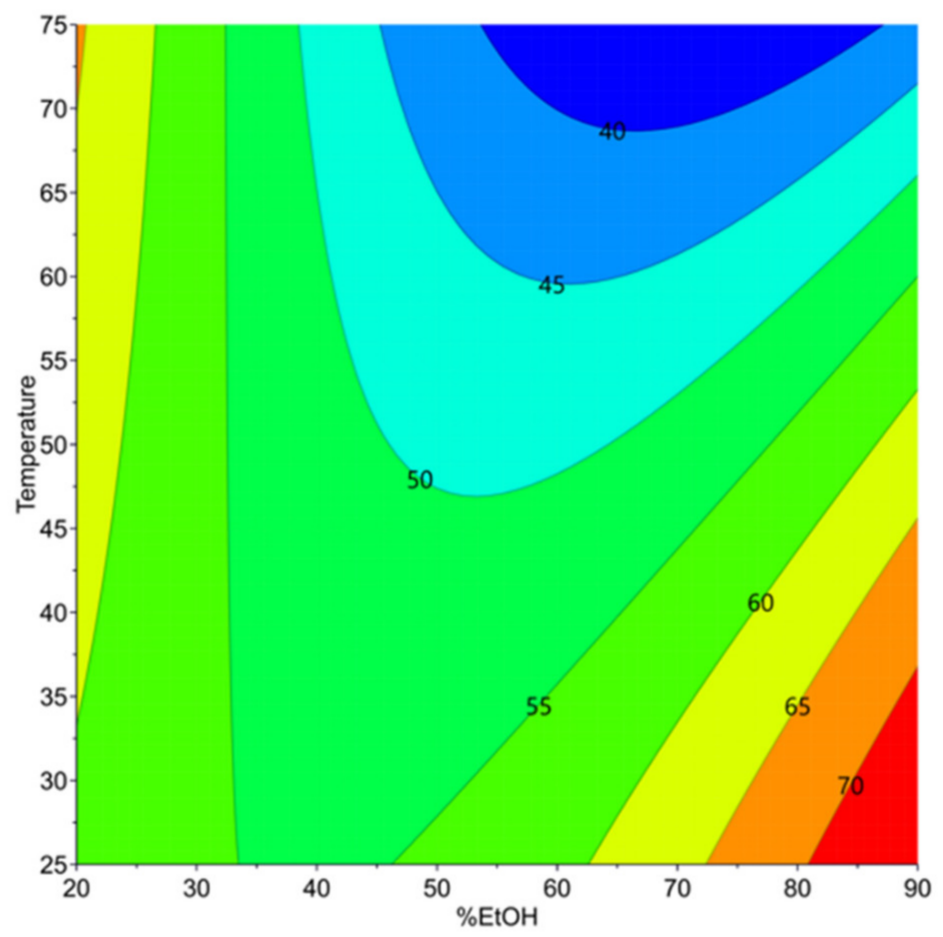

Figure 3. Contour plot for the prediction of extractability index (\%) of proteins. Dashed red triangle indicates optimal zone of protein extractability index.

According to Table 2, the most significant terms in the model equation providing $\mathrm{Y}_{3}$ are the quadratic term for the ethanol concentration $(\% \mathrm{EtOH} \times \% \mathrm{EtOH})$, which has a positive effect on the protein extractability and the extraction temperature $T_{e}$, and the interaction term $\left(\mathrm{T}_{\mathrm{e}} \times \% \mathrm{EtOH}\right)$, which has a negative impact (Figure 3$)$.

The prior AE extraction of secondary metabolites decreases the extractability of proteins during alkaline extraction, regardless of the operating conditions. The prediction model indicates a sharp decrease in protein extractability $\left(\mathrm{Y}_{3}\right)$ when moderate \%EtOH (40-70\%) and $\mathrm{T}_{\mathrm{e}}$ above $45^{\circ} \mathrm{C}$ are applied. This is due to the high protein recovery with secondary metabolites during $\mathrm{AE}$ extraction, resulting in lower protein availability in the treated meal during alkaline extraction.

The prediction model also indicates that a high extractability of the proteins is retained when AE extraction of secondary metabolites is performed with a high $\% \mathrm{EtOH}(>80 \%)$ at low $\mathrm{T}_{\mathrm{e}}\left(<35^{\circ} \mathrm{C}\right)$, or with $20 \% \mathrm{EtOH}$ at high $\mathrm{T}_{\mathrm{e}}\left(>70{ }^{\circ} \mathrm{C}\right)$. To better understand these results, the polypeptide profile of alkaline extracts was studied by SDS-PAGE analysis under non-reducing conditions

\subsubsection{Effects of Optimal Aqueous Ethanol Extraction on Carinata Protein Profile}

Figure 4 presents the polypeptide profile obtained by SDS-PAGE for the different experiments of D-optimal design. The main Carinata proteins included, albumin (napin) and globulin (cruciferin), are attributed to the bands at $15 \mathrm{kDa}$ and $50 \mathrm{kDa}$, respectively [6]. The bands at $30 \mathrm{kDa}$ correspond to free polypeptide chains dissociated from cruciferin. 

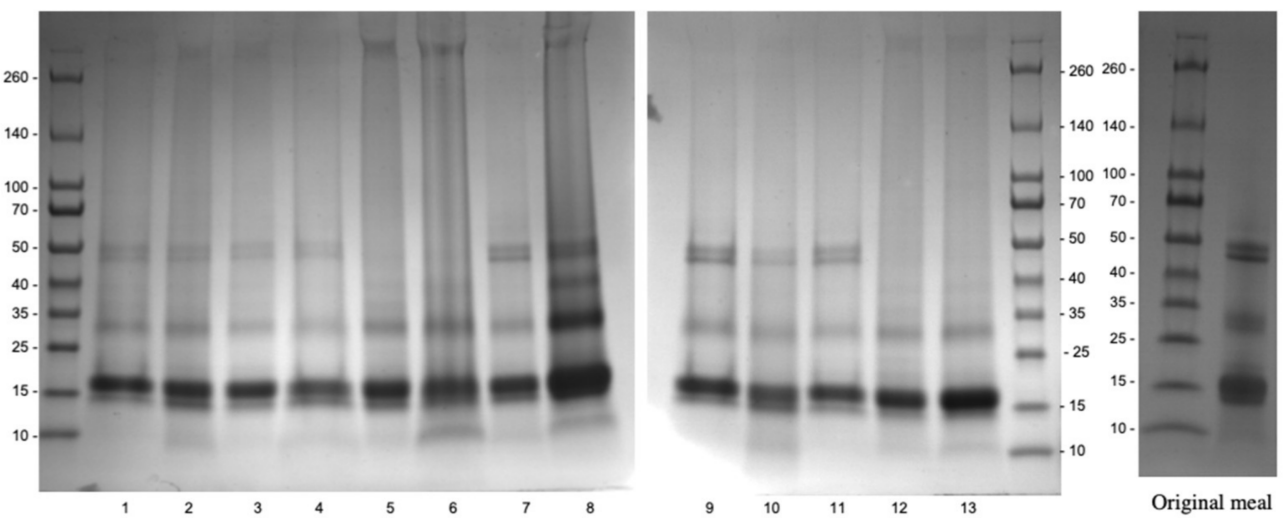

Figure 4. Polypeptide profiles of alkaline extracts from residual Carinata meal upon aqueous ethanol extraction. The numbers below indicate the experiments of D-optimal design described in Table 1.

The most important difference between the profiles of alkaline extracts obtained during the experimental design and the control is the change of the $50 \mathrm{kDa}$ bands (cruciferins). At an extraction temperature of $75^{\circ} \mathrm{C}$, the disappearance of these bands was observed (lanes 6 , 12 and 13, Figure 4). Hence, cruciferin was either completely removed during the recovery of secondary metabolites, or dissociated when exposed to high temperatures during the AE extraction process [23].

The optimal operating conditions of the AE extraction process to maximize $\mathrm{Y}_{3}$, calculated by the MODDE software, are $\% \mathrm{EtOH}=90 \%$ and $\mathrm{T}_{\mathrm{e}}=25^{\circ} \mathrm{C}$. Under these conditions, the EI of proteins during alkaline extraction was the highest, and reached $76.0 \pm 3.8 \%$. No significant difference (Table S3) was found between the values predicted and those observed $(78.8 \pm 0.7 \%)$, thus validating the prediction model of EI.

Unfortunately, these optimal operating conditions are antagonistic to those for the recovery of secondary metabolites. Reaching a compromise leading to a high recovery of secondary metabolites while maintaining high protein EI is therefore discussed in the next section.

\subsection{Determination of Operating Conditions for the Optimization of $Y_{1}, Y_{2}$, and $Y_{3}$}

A 3D graph representing the $Y_{1}, Y_{2}$, and $Y_{3}$ responses as a function of $\% E t O H$ and $\mathrm{T}_{\mathrm{e}}$ was drawn to visualize the areas for which the recovery of secondary metabolites is maximal, with minimal loss of protein extractability (Figure 5).

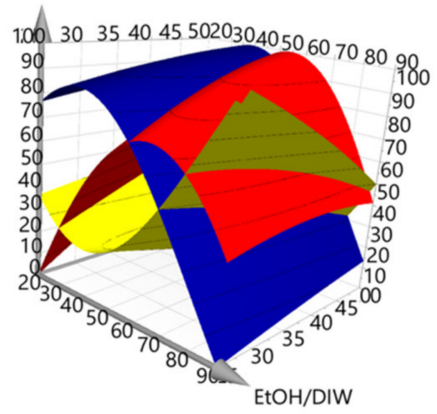

(a)

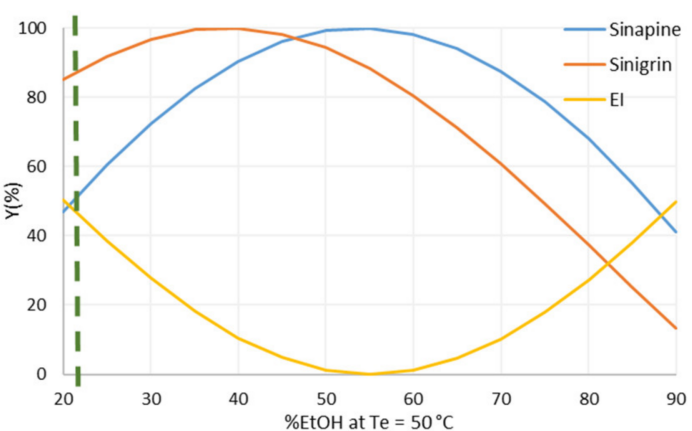

(b)

Figure 5. (a) Response surface plot of three main factors (PC content, GSL content, and EI) required to reach a compromise between the recovery of secondary metabolites and protein extractability upon $\mathrm{AE}$ treatment. The response values were scaled so that the minima and maxima were set at 0 and $100 \%$, respectively; (b) Plotting chart to determine the desired compromise at $50{ }^{\circ} \mathrm{C}$. The $\mathrm{X}$ axis was limited to $50 \%$ to visualize the reached compromise between selected responses. 
From the response surface plot generated by the experimental design software, it is difficult to define the precise operating conditions that would enable the best compromise between the three responses. This is due to complex antagonistic effects between the recovery of secondary metabolites and protein extractability, as depicted in Figure $5 \mathrm{a}$. However, a more precise evaluation could be carried out using 2D graphs. Consequently, the three responses are plotted as a function of $\% \mathrm{EtOH}$, varying from 20 to $90 \%$ for a given extraction temperature. Figure $5 b$ presents one of the graphs showing the evolution of $Y_{1}$, $\mathrm{Y}_{2}$, and $\mathrm{Y}_{3}$ as a function of $\% \mathrm{EtOH}$, for $\mathrm{T}_{\mathrm{e}}=50{ }^{\circ} \mathrm{C}$. To obtain the highest values for the three responses, 22\% ethanol must be used. The other graphs are shown in Figure S3. For each graph, an optimal percentage of ethanol was determined. The results are presented in Table 3.

Table 3. Values of PC and GSL contents $\left(Y_{1}\right.$ and $\left.Y_{2}\right)$ and the extractability index $\left(Y_{3}\right)$ associated with each $\%$ EtOH optimum according to $T_{e}$.

\begin{tabular}{ccccc}
\hline $\begin{array}{c}\mathrm{T}_{\mathbf{e}} \\
\left({ }^{\circ} \mathbf{C}\right)\end{array}$ & $\begin{array}{c}\text { Optimal } \\
\text { \%EtOH }\end{array}$ & $\mathbf{Y}_{\mathbf{1}}\left(\mathbf{m g} / \mathbf{g}_{\mathbf{D M}}\right)$ & $\mathbf{Y}_{\mathbf{2}}\left(\boldsymbol{\mu \mathbf { m o l } / \mathbf { g } _ { \mathrm { DM } } )}\right.$ & $\mathbf{Y}_{\mathbf{3}} \mathbf{( \% )}$ \\
\hline 25 & $67 \%$ & $9.94^{\mathrm{a}} \pm 0.08$ & $71.47^{\mathrm{b}} \pm 0.90$ & $62.15^{\mathrm{a}} \pm 0.56$ \\
30 & $70 \%$ & $10.10^{\mathrm{a}} \pm 0.08$ & $70.31^{\mathrm{b}, \mathrm{c}} \pm 0.92$ & $61.56^{\mathrm{a}} \pm 0.57$ \\
35 & $73 \%$ & $10.13^{\mathrm{a}} \pm 0.09$ & $68.63^{\mathrm{c}, \mathrm{d}} \pm 0.92$ & $60.85^{\mathrm{a}, \mathrm{b}} \pm 0.58$ \\
40 & $77 \%$ & $10.01^{\mathrm{a}} \pm 0.09$ & $66.89^{\mathrm{d}} \pm 0.93$ & $60.45^{\mathrm{b}} \pm 0.59$ \\
45 & $23 \%$ & $9.09^{\mathrm{b}} \pm 0.09$ & $92.19^{\mathrm{a}} \pm 0.93$ & $59.94^{\mathrm{b}} \pm 0.60$ \\
50 & $22 \%$ & $9.15^{\mathrm{b}} \pm 0.09$ & $91.02^{\mathrm{a}} \pm 0.93$ & $61.12^{\mathrm{a}} \pm 0.61$ \\
\hline
\end{tabular}

Letters associated with the means correspond to equivalent values according to the Tukey's test.

For each $\mathrm{T}_{\mathrm{e}}$, the \%EtOH resulting in the highest values of $\mathrm{Y}_{1}, \mathrm{Y}_{2}$, and $\mathrm{Y}_{3}$ was determined. The corresponding response values predicted by the model are also shown in Table 3.

Thus, it was noticed that the optimal \%EtOH depends on $\mathrm{T}_{\mathrm{e}}$. For temperatures below $40{ }^{\circ} \mathrm{C}$, the optimal \%EtOH is between 67 and $77 \%$, whereas for temperatures of 45 and $50{ }^{\circ} \mathrm{C}$, only 22 or $23 \%$ ethanol is needed to obtain the highest values of $\mathrm{Y}_{1}, \mathrm{Y}_{2}$, and $\mathrm{Y}_{3}$. These results are consistent with the two optimal zones described from Figure 3 for maximizing the protein extractability index.

According to Table 3, two combinations of operating conditions can be chosen to simultaneously reach the optimal values of the three responses. The first combination corresponds to a low $\mathrm{T}_{\mathrm{e}}\left(25^{\circ} \mathrm{C}\right)$ with $67 \%$ ethanol, which yields $9.94 \pm 0.08 \mathrm{mg} / \mathrm{g}_{\mathrm{DM}}$ of $\mathrm{PC}$ and $71.47 \pm 0.90 \mu \mathrm{mol} / \mathrm{g}_{\mathrm{DM}}$ of GSL, with an IE of $62.15 \pm 0.56 \%$. These conditions maximize the PC content and the protein EI. The second combination allows an extraction at $50{ }^{\circ} \mathrm{C}$ with $22 \% \mathrm{EtOH}$ to yield a PC content at $9.15 \pm 0.09 \mathrm{mg} / \mathrm{g}_{\mathrm{DM}}$, a GSL content at $91.02 \pm 0.93 \mu \mathrm{mol} / \mathrm{g}_{\mathrm{DM}}$, and an EI of $61.12 \pm 0.61 \%$. In this case, it is the GSL content and the EI that are maximized. In order to develop a sustainable extraction process, our choice will be the second combination, which minimizes the amount of solvent used.

For these operating conditions, extractions were carried out, and experimental values were statistically equivalent to the values predicted by the models (Table S3). Thus, this reinforces the validation of the prediction models of $Y_{1}, Y_{2}$, and $Y_{3}$, determined previously.

\subsection{Effect of the New Operating Conditions on Functional Properties of Carinata Proteins upon Aqueous Ethanol Extraction}

Functional properties of Brassica proteins, such as foaming and emulsifying capacities, are of great interest [10,40] and directly depend on their 3D structures [7]. According to the literature, these functional properties can be considered significant indicators of the effect of AE extraction on proteins. The emulsifying activity index (EAI), emulsifying stability (ES), foaming activity (FA), and foaming stability (FS) of protein isolates from original meal and treated meal under the selected extraction conditions (i.e., $22 \% \mathrm{EtOH}$ at $50{ }^{\circ} \mathrm{C}$ ) are shown in Table 4. 
Table 4. Protein content and functional properties of Carinata protein isolates of original and treated meal.

\begin{tabular}{ccccc}
\hline Type of Meal & EAI $\left(\mathbf{m}^{\mathbf{2}} \mathbf{g}\right)$ & ES $\mathbf{( \% )}$ & FA (\%) & FS (\%) \\
\hline Original meal & $10.7 \pm 1.4$ & $63.5 \pm 0.2$ & $123.8 \pm 1.8$ & $94.9 \pm 1.5$ \\
$\begin{array}{c}\text { Treated meal } \\
\begin{array}{c}\text { Student's test } \\
(p \text {-value })\end{array}\end{array}$ & $10.0 \pm 0.6$ & $61.4 \pm 1.1$ & $147.3 \pm 3.2$ & $94.2 \pm 1.6$ \\
\hline
\end{tabular}

According to the Student's $t$-test, EAI and FS values of protein isolates from both original and treated Carinata meal were quite similar. Although the ES of original meal was significantly higher than that of the treated meal, this loss remained low, considering the value of ES. The results were consistent with the functional properties of Carinata protein isolated at $\mathrm{pH} 12$ reported by Pedroche et al. [3]. The ES value, on the other hand, corresponded to that of a protein isolate prepared at $\mathrm{pH} 10$, as reported in the literature [3]. These differences might be due to the difference between the analytical methods employed.

The FA of treated meal was higher than that of original meal, whereas the FS of both protein isolates were similar, and were also comparable to protein isolate from defatted canola meal [8]. These results suggested that the removal of secondary metabolites modified the composition in proteins, and eventually their structure, leading to higher foaming capacity of protein isolate from treated meal.

Taken together, these results revealed that the changes in functional properties of treated meal upon $\mathrm{AE}$ extraction of Carinata meal with $22 \% \mathrm{EtOH}$ at $50{ }^{\circ} \mathrm{C}$ improved the foaming activity, while preserving other functional properties of protein isolates.

\section{Conclusions}

Optimization of AE extraction of Carinata meal with aqueous ethanol resulted in validated models based on selected factors and responses. These models predicted that extraction with low $\% \mathrm{EtOH}$ at moderate $T_{e}$ afforded the best balance between the efficiency of metabolite recovery from Carinata meal and the protein extractability of treated meals following AE extraction, while preserving the functional properties of protein isolates. Although metabolites recovered from Carinata meal were not individually separated in this study, preparative chromatography can be employed for this purpose. Moreover, the phytic acid recovery during the $\mathrm{AE}$ and alkaline extraction was disregarded in this study. Thereby, future work will address not only the separation of GSLs and PCs from $\mathrm{AE}$ extracts, but also the effects of our process on the recovery of phytic acid present in the meal. In addition, further research on Carinata proteins is ongoing, in order to determine the structural changes caused by AE extraction.

Supplementary Materials: The following supporting information can be downloaded at: https: / / www.mdpi.com/article/10.3390/foods11030429/s1, Table S1. Phenolic compound content of AE and alkaline extracts; Table S2. Glucosinolate content of AE and alkaline extracts; Table S3. Extern validation of prediction models; Table S4. Extractability index (EI) of proteins of AE and alkaline extracts; Figure S1. Phenolic compound analysis by HPLC of AE extracts under different extraction conditions; Figure S2. Glucosinolates analysis by HPLC of AE extracts under different extraction conditions; and Figure S3. Plotting chart to determine desired compromise at different temperatures from 25 to $50^{\circ} \mathrm{C}$.

Author Contributions: Conceptualization, I.I.; investigation and formal analysis, V.P.T.N.; supervision, I.I.; writing—original draft preparation, V.P.T.N.; writing—review and editing, I.I., F.A., and J.D.S.; funding acquisition, F.A. and J.D.S. All authors have read and agreed to the published version of the manuscript.

Funding: This work was supported by the National Institute of Food and Agriculture, United States Department of Agriculture, under award number 2016-11231. 
Data Availability Statement: The data presented in this study are available in the article and in the supplementary file.

Acknowledgments: The authors also thank Grand Reims, Département de la Marne and Grand Est region, as well as the Fondation Paris-Reims, for funding.

Conflicts of Interest: The authors declare no conflict of interest. The funders had no role in the design of the study; in the collection, analyses, or interpretation of data; in the writing of the manuscript, or in the decision to publish the results.

\section{References}

1. Christ, B.; Bartels, W.L.; Broughton, D.; Seepaul, R.; Geller, D. In Pursuit of a Homegrown Biofuel: Navigating Systems of Partnership, Stakeholder Knowledge, and Adoption of Brassica Carinata in the Southeast United States. Energy Res. Soc. Sci. 2020, 70, 101665. [CrossRef]

2. SPARC. Southeast Partnership for Advanced Renewables from Carinata. Available online: https://Sparc-Cap.Org (accessed on 22 June 2021).

3. Pedroche, J.; Yust, M.M.; Lqari, H.; Girón-Calle, J.; Alaiz, M.; Vioque, J.; Millán, F. Brassica Carinata Protein Isolates: Chemical Composition, Protein Characterization and Improvement of Functional Properties by Protein Hydrolysis. Food Chem. 2004, 88, 337-346. [CrossRef]

4. Seepaul, R.; Small, I.M.; Mulvaney, M.J.; George, S.; Leon, R.G.; Geller, D.; Wright, D.L. Carinata, the Sustainable Crop for a Bio-Based Economy: 2018-2019 Production Recommendations for the Southeastern United States; University of Florida Institute of Food and Agricultural Sciences: Gainesville, FL, USA, 2019; pp. 1-12.

5. Aider, M.; Barbana, C. Canola Proteins: Composition, Extraction, Functional Properties, Bioactivity, Applications as a Food Ingredient and Allergenicity-A Practical and Critical Review. Trends Food Sci. Technol. 2011, 22, 21-39. [CrossRef]

6. Tan, S.H.; Mailer, R.J.; Blanchard, C.L.; Agboola, S.O. Extraction and Characterization of Protein Fractions from Australian Canola Meals. Food Res. Int. 2011, 44, 1075-1082. [CrossRef]

7. Wanasundara, J.P.D. Proteins of Brassicaceae Oilseeds and Their Potential as a Plant Protein Source. Crit. Rev. Food Sci. Nutr. 2011, 51, 635-677. [CrossRef]

8. Akbari, A.; Wu, J. An Integrated Method of Isolating Napin and Cruciferin from Defatted Canola Meal. LWT Food Sci. Technol. 2015, 64, 308-315. [CrossRef]

9. Wu, J.; Muir, A.D. Comparative Structural, Emulsifying, and Biological Properties of 2 Major Canola Proteins, Cruciferin and Napin. J. Food Sci. 2008, 73, M1-M8. [CrossRef]

10. Akbari, A.; Lavasanifar, A.; Wu, J. Interaction of Cruciferin-Based Nanoparticles with Caco-2 Cells and Caco-2/HT29-MTX Co-Cultures. Acta Biomater. 2017, 64, 249-258. [CrossRef]

11. Wang, F.; Yang, Y.; Ju, X.; Udenigwe, C.C.; He, R. Polyelectrolyte Complex Nanoparticles from Chitosan and Acylated Rapeseed Cruciferin Protein for Curcumin Delivery. J. Agric. Food Chem. 2018, 66, 2685-2693. [CrossRef]

12. Chen, R.; Wang, X.-J.; Zhang, Y.-Y.; Xing, Y.; Yang, L.; Ni, H.; Li, H.-H. Simultaneous Extraction and Separation of Oil, Proteins, and Glucosinolates from Moringa Oleifera Seeds. Food Chem. 2019, 300, 125162. [CrossRef]

13. Nguyen, V.P.T.; Stewart, J.D.; Ioannou, I.; Allais, F. Sinapic Acid and Sinapate Esters in Brassica: Innate Accumulation, Biosynthesis, Accessibility via Chemical Synthesis or Recovery from Biomass, and Biological Activities. Front. Chem. 2021, 9, 664602. [CrossRef] [PubMed]

14. Mazumder, A.; Dwivedi, A.; du Plessis, J. Sinigrin and Its Therapeutic Benefits. Molecules 2016, 21, 416. [CrossRef] [PubMed]

15. Nićiforović, N.; Abramovič, H. Sinapic Acid and Its Derivatives: Natural Sources and Bioactivity. Compr. Rev. Food Sci. Food Saf. 2014, 13, 34-51. [CrossRef] [PubMed]

16. Zhou, J.R.; Erdman, J.W. Phytic Acid in Health and Disease. Crit. Rev. Food Sci. Nutr. 1995, 35, 495-508. [CrossRef]

17. Griffiths, D.W.; Birch, A.N.E.; Hillman, J.R. Antinutritional Compounds in the Brassicaceae: Analysis, Biosynthesis, Chemistry and Dietary Effects. J. Hortic. Sci. Biotechnol. 1998, 73, 1-18. [CrossRef]

18. Chuo, S.C.; Nasir, H.M.; Mohd-Setapar, S.H.; Mohamed, S.F.; Ahmad, A.; Wani, W.A.; Muddassir, M.; Alarifi, A. A Glimpse into the Extraction Methods of Active Compounds from Plants. Crit. Rev. Anal. Chem. 2020, 20, 1-30. [CrossRef]

19. Fang, J.; Reichelt, M.; Kai, M.; Schneider, B. Metabolic Profiling of Lignans and Other Secondary Metabolites from Rapeseed (Brassica napus L.). J. Agric. Food Chem. 2012, 60, 10523-10529. [CrossRef]

20. Flourat, A.L.; Willig, G.; Teixeira, A.R.S.; Allais, F. Eco-Friendly Extraction of Sinapine from Residues of Mustard Production. Front. Sustain. Food Syst. 2019, 3, 12. [CrossRef]

21. Li, J.; Guo, Z. Complete Utilization of Rapeseed Meal to Produce Lipophilic Antioxidants, Protein, and Monosugars in a Concordant Manner. ACS Sustain. Chem. Eng. 2017, 5, 6218-6226. [CrossRef]

22. Reungoat, V.; Gaudin, M.; Flourat, A.L.; Isidore, E.; Mouterde, L.M.M.; Allais, F.; Ducatel, H.; Ioannou, I. Optimization of an Ethanol/Water-Based Sinapine Extraction from Mustard Bran Using Response Surface Methodology. Food Bioprod. Process. 2020, 122, 322-331. [CrossRef] 
23. Laguna, O.; Odinot, E.; Bisotto, A.; Baréa, B.; Villeneuve, P.; Sigoillot, J.C.; Record, E.; Faulds, C.B.; Fine, F.; Lesage-Meessen, L.; et al. Release of Phenolic Acids from Sunflower and Rapeseed Meals Using Different Carboxylic Esters Hydrolases from Aspergillus Niger. Ind. Crop. Prod. 2019, 139, 111579. [CrossRef]

24. Lin, L.-Z.; Harnly, J.M. Phenolic Component Profiles of Mustard Greens, Yu Choy, and 15 Other Brassica Vegetables. J. Agric. Food Chem. 2010, 58, 6850-6857. [CrossRef] [PubMed]

25. Kalaydzhiev, H.; Georgiev, R.; Ivanova, P.; Stoyanova, M.; Silva, C.L.M.; Chalova, V.I. Enhanced Solubility of Rapeseed Meal Protein Isolates Prepared by Sequential Isoelectric Precipitation. Foods 2020, 9, 703. [CrossRef] [PubMed]

26. Wanasundara, J.P.D.; McIntosh, T.C.; Perera, S.P.; Withana-Gamage, T.S.; Mitra, P. Canola/Rapeseed Protein-Functionality and Nutrition. OCL 2016, 23, D407. [CrossRef]

27. Kalaydzhiev, H.; Ivanova, P.; Stoyanova, M.; Pavlov, A.; Rustad, T.; Silva, C.L.M.; Chalova, V.I. Valorization of Rapeseed Meal: Influence of Ethanol Antinutrients Removal on Protein Extractability, Amino Acid Composition and Fractional Profile. Waste Biomass Valorization 2020, 11, 2709-2719. [CrossRef]

28. Mouterde, L.M.M.; Peru, A.A.M.; Mention, M.M.; Brunissen, F.; Allais, F. Sustainable Straightforward Synthesis and Evaluation of the Antioxidant and Antimicrobial Activity of Sinapine and Analogues. J. Agric. Food Chem. 2020, 68, 6998-7004. [CrossRef]

29. AOAC International. AOAC Official Methods for Analysis Association of Official Analytical Chemists; AOAC International: Rockville, MD, USA, 2000.

30. Dubois, M.; Gilles, K.A.; Hamilton, J.K.; Rebers, P.A.; Smith, F. Colorimetric Method for Determination of Sugars and Related Substances. Anal. Chem. 1956, 28, 350-356. [CrossRef]

31. Reichwald, K.; Hatzack, F. Application of a Modified Haug and Lantzsch Method for the Rapid and Accurate Photometrical Phytate Determination in Soybean, Wheat, and Maize Meals. J. Agric. Food Chem. 2008, 56, 2888-2891. [CrossRef]

32. Grosser, K.; van Dam, N.M. A Straightforward Method for Glucosinolate Extraction and Analysis with High-Pressure Liquid Chromatography (HPLC). J. Vis. Exp. 2017, 121, 55425. [CrossRef]

33. Perera, S.P.; McIntosh, T.C.; Wanasundara, J.P.D. Structural Properties of Cruciferin and Napin of Brassica Napus (Canola) Show Distinct Responses to Changes in PH and Temperature. Plants 2016, 5, 64-74. [CrossRef]

34. Aluko, R.E.; McIntosh, T. Polypeptide Profile and Functional Properties of Defatted Meals and Protein Isolates of Canola Seeds. J. Sci. Food Agric. 2001, 81, 391-396. [CrossRef]

35. Pearce, K.N.; Kinsella, J.E. Emulsifying Properties of Proteins: Evaluation of a Turbidimetric Technique. J. Agric. Food Chem. 1978, 26, 716-723. [CrossRef]

36. Xin, H.; Yu, P. Chemical Profile, Energy Values, and Protein Molecular Structure Characteristics of Biofuel/Bio-Oil Co-Products (Carinata Meal) in Comparison with Canola Meal. J. Agric. Food Chem. 2013, 61, 3926-3933. [CrossRef] [PubMed]

37. Fernandes, F.; Valentão, P.; Sousa, C.; Pereira, J.A.; Seabra, R.M.; Andrade, P.B. Chemical and Antioxidative Assessment of Dietary Turnip (Brassica rapa var. Rapa L.). Food Chem. 2007, 105, 1003-1010. [CrossRef]

38. Laguna, O.; Barakat, A.; Alhamada, H.; Durand, E.; Baréa, B.; Fine, F.; Villeneuve, P.; Citeau, M.; Dauguet, S.; Lecomte, J. Production of Proteins and Phenolic Compounds Enriched Fractions from Rapeseed and Sunflower Meals by Dry Fractionation Processes. Ind. Crop. Prod. 2018, 118, 160-172. [CrossRef]

39. Nguyen, V.P.T.; Stewart, J.; Lopez, M.; Ioannou, I.; Allais, F. Glucosinolates: Natural Occurrence, Biosynthesis, Accessibility, Isolation, Structures, and Biological Activities. Molecules 2020, 25, 4537. [CrossRef] [PubMed]

40. Fetzer, A.; Herfellner, T.; Stäbler, A.; Menner, M.; Eisner, P. Influence of Process Conditions during Aqueous Protein Extraction upon Yield from Pre-Pressed and Cold-Pressed Rapeseed Press Cake. Ind. Crop. Prod. 2018, 112, 236-246. [CrossRef] 